\title{
PIERRE ROBIN SEQUENCE AND OBSTRUCTIVE SLEEP APNEA
}

\author{
RUBENS REIMÃO*, ELIO GIACOMO PAPAIZ**, LUIZ FERNANDO PAPAIZ***
}

SUMMARY - The case of a 12-year-old female patient with Pierre Robin sequence is reported, in which reduction of the pharyngeal airway leads to obstructive sleep apnea syndrome (OSAS) and excessive daytime sleepiness. Radiological evaluation, computerized tomography and magnetic resonance image showed bilateral temporomandibular ankylosis. Cephalometric data evidenced marked reduction of the posterior airway space. Three all-night polysomnographic evaluations detected severe OSAS with decrease in oxygen saturation. The Multiple Sleep Latency Test (MSLT) perfomed on two separate days objectively quantified the excessive daytime sleepiness with short sleep latencies; stage REM was not present. Polysomnography, MSLT and thorough radiologic studies, in this case, made it possible to determine the severity of OSAS, the site of obstruction, and the associated malformations.

KEY WORDS: sleep apnea syndrome, apnea, Pierre Robin, sleep, polysomnography, cephalometrics.

\section{Sequência de Pierre Robin e apnéia do sono tipo obstrutivo}

RESUMO - É relatado o caso de paciente do sexo feminino de 12 anos de idade, com sequência de Pierre Robin, cuja redução da luz faríngea leva a apnéia do sono tipo obstrutivo e consequente sonolência excessiva diurna. Estudo radiológico articular, tomografia computadorizada e ressonância nuclear magnética evidenciam anquilose bilateral da articulação têmporo-mandibular. Cefalometria mostra redução acentuada do espaço aéreo posterior. Polissonografia realizada durante três noites inteiras apresenta síndrome de apnéia do sono tipo obstrutivo, severa, acompanhada de redução da saturação de oxigênio. No Teste das Latências Múltiplas do Sono (TLMS) há objetivamente sonolência excessiva diurna, com descréscimo da latência do sono; não ocorre estágio REM. Avaliação polissonográfica, do TLMS e radiológica extensa permitem, neste caso, estagiar a severidade de acometimento e as malformações concomitantes e detectar o sítio de obstrução.

PALAVRAS-CHAVE: síndrome de apnéia do sono, apnéia, Pierre Robin, sono, polissonografia, cefalometria.

The Pierre Robin syndrome is characterized by micrognathia, frequent glossoptosis, and high or cleft palate. Pierre Robin sequence, on the other hand, may show a wider spectrum of impairment. Initially there may be mandibular hypoplasia which often leads to the failure of palatal closure due to the posteriorly located tongue. The receding chin, and glossoptosis may be associated with malformations mainly of the first and second arch derivations. Breathing difficulty may be evident in syndromes that accompany micrognathia, the backward dispalced tongue tending to encroach on the airway, leading to complete or partial pharyngeal obstruction and hypoxia; chronic airway obstruction and feeding difficulties accompanied by cor pulmonale and failure to thrive ${ }^{5.21}$. Few studies deal with objective polysomnographic evaluation of these patients $\mathrm{s}^{\mathbf{3 . 7 . 8 . 1 4}, 15}$.

*Department of Neurology, Hospital das Clínicas, University of São Paulo Medical School and Sleep Disorders Center, Reimão Clinic, São Paulo; **Department of Radiology, Dentistry School, University of São Francisco, Bragança Paulista, São Paulo; ***Fellow in Radiology, São Paulo Dentistry Association. Aceite: 29abril-1994. 
In this paper, we report a case of Pierre Robin sequence with prominent obstructive sleep apnea syndrome (OSAS), showing the clinical, radiological and polysomnographic roles in the evaluation.

\section{CASE REPORT}

Case A (Reg 4050505 A), a 12 year old female patient, was referred to sleep evaluation for having presented excessive daytime sleepiness since the first year of life. Her sleepiness has been moderate or intense throughout the years and has never ceased for periods of more than a few hours. At this point, her sleepiness is such to cause frequent naps in class and to prevent her from following class activities. In spite of this she has never failed a school year, due to her after hour efforts and support. She also naps while talking, reading, attending class activities or in any other monotonous situation. At nigth, her sleep is described as restless, with intense movements related to labored breathing and loud snoring. Her most usual sleeping position is sitting on the edge of the bed with the head tilted forward, often sleeping while kneeling on the floor with her head and shoulder resting on the bed. Long apneas are decribed by the family. On school days, she usually sleeps at 2100 $h$ and wakes up 2 or 3 times to urinate in the toillet, immediately thereafter returning to sleep, and then wakes up for the day at $0615 \mathrm{~h}$. She needs strong stimuli from her family to wake up each morning. On the weekends, she sleeps at $2100 \mathrm{~h}$ and wakes up at $1230 \mathrm{~h}$ and regularly takes mid-afternoon naps for $45 \mathrm{~min}$. Mild morning frontal headaches have been frequent for the last two years.

The diagnosis of Pierre Robin sequence had been established from birth, because of the presence of micrognathia, glossoptosis, high palate, and mandibular ankylosis. The past history shows that gestation and birth were uneventful but on second day of life suckling difficulty and choking spells were noticed. Broncopneumonia was diagnosed on the second week of life and again on the second month of life. She was submitted to surgery of the right mandibular condile when she was 4 years old without noticeable change. At age of 10 years she underwent turbinectomy, also without appreciable improvement. Her developmental milestones were normal. Family history was unremarkable, the patient was the third of five children; there were no similar cases nor consanguinity in the family. General physical examination showed weigth $40 \mathrm{~kg}$; height $141 \mathrm{~cm}$ : BP $105 \times 70 \mathrm{mmHg}$. Her face was asymmetric with more marked atrophy of the right inferior third of the face.

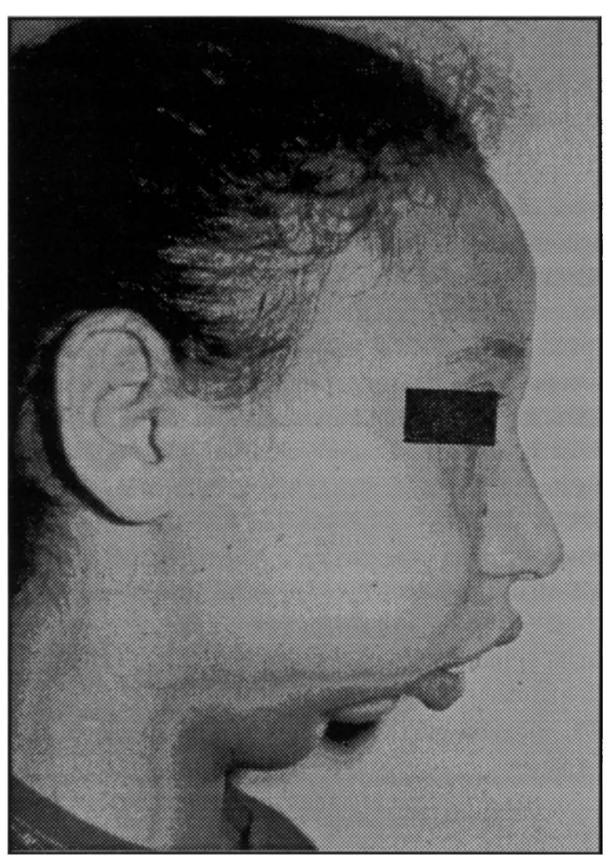

Fig 1. Case A, a twelve-year-old female with micrognathia.
There were mandibular hypoplasia (Fig 1); bilateral temporomandibular ankylosis without articular mouth opening movement; lingual ptosis; mouth breathing. Palate could not be observed due to lack of mouth opening movement. Neurological and cardiological examinations were normal. Neuropsychological evaluation showed normal praxias, gnosias and language. Wechsler Intelligence Scale for Children (WISC) scores were in the lower limits for verbal as well as nonverbal subtests; Raven test and Benton Gestalt test were normal. During the interviews, the patient is a shy and insecure adolescent. Laboratory examinations revealed normal: blood and ion study result; urine; serologic studies for syphilis, Chagas disease, type B hepatitis, HIV; electrocardiogram; electroencephalogram; and cranial computerized tomography.

Temporomandibular articulation and panoramic roentogenograms showed ankylosis of the mandibular condiles and a lack of well defined contours of the temporomandibular joints and right articular fossa. Temporomandibular joint computerized tomography showed reduction and flattening of the rigth glenoid articulation, with lack of contours of temporal and mandibular bone portions, with consequent flattening of the mandibular condile, with ankylosis. Flattening and enlargement of the left glenoid cavity, with external 


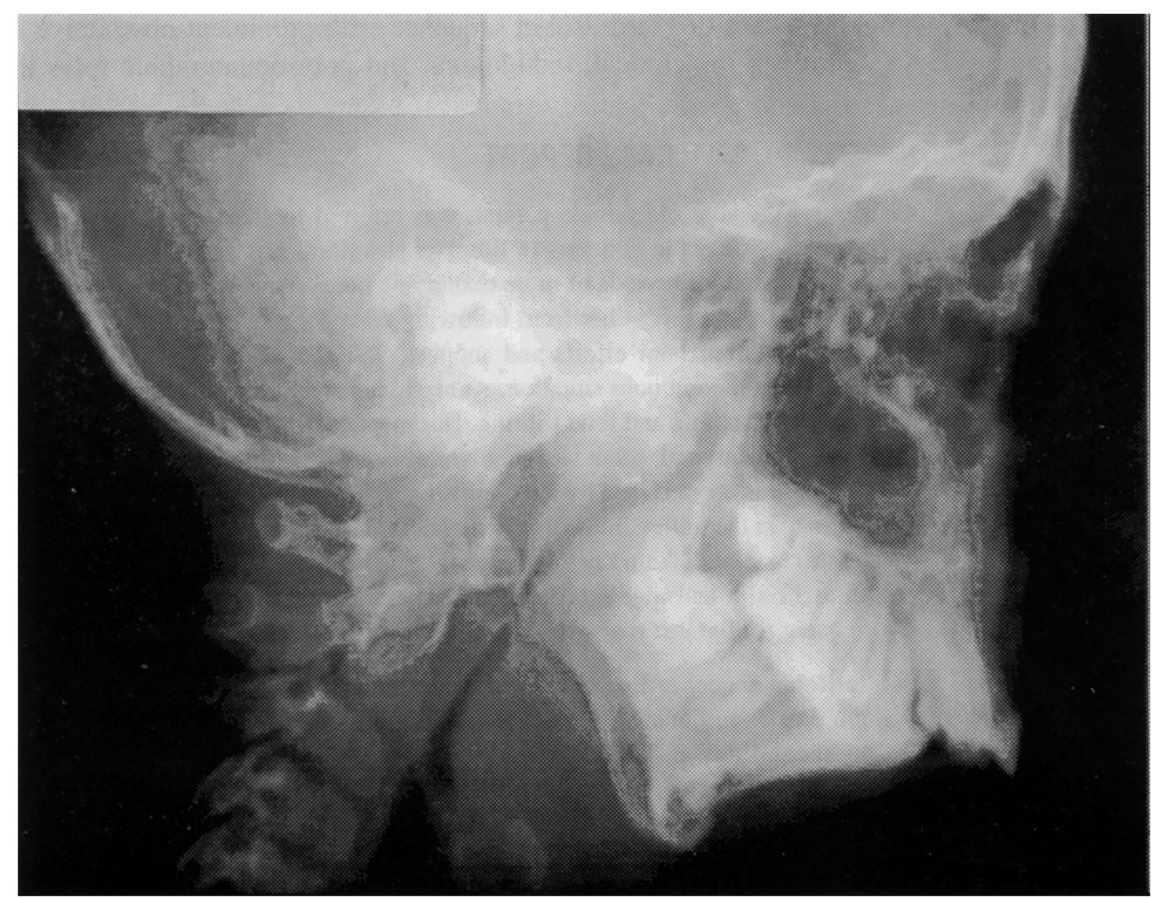

Fig 2. Case A, cephalometric roentgenogram. Micrognathia with marked posterior airway space (PAS) reduction.

subluxation of the mandibular condyle, which shows hypotrophy. Nuclear magnetic resonance showed hypoplasia of the mandibule with anterior protusion of the teeth and reduction of the bucal cavity. The hard palate is thin and high but without cleft. Limphadenomegaly of the lateral chains was observed.

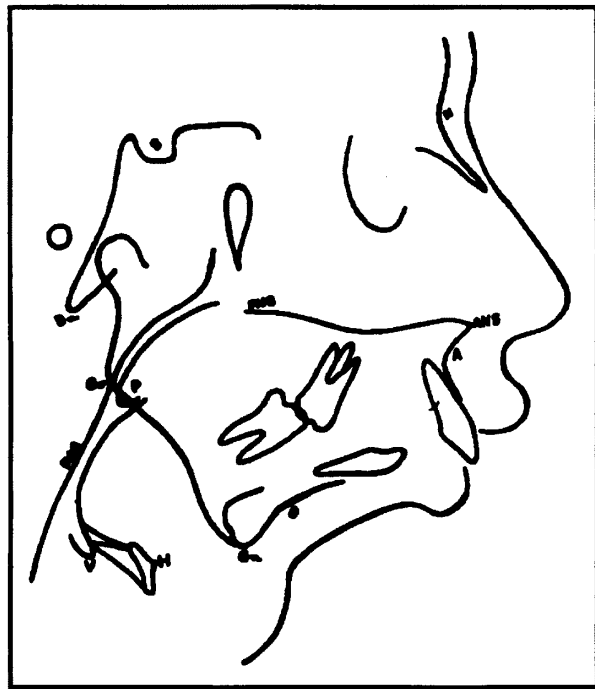

Fig 3. Sketch with main anatomical points.
Conventional lateral cephalometric radiographs were obtained, with head fixed with a cephalostat, according to standardized technique and nomenclature $^{6,10,20,23,24}$ (Fig 2 and 3). In this case, cephalometric data showed marked reduction of the posterior airway space (PAS) due to tongue backward displacement secondary to micrognathia. Cephalometric indices were: SNA, angle measurement from sella to nasion to point $A, 84.98 ; \mathrm{SNB}$, angle measurement from sella to nasion to point $B, 61.11$; ANB, difference between SNA and SNB, 23.83; PAS, 2.03; PNS-P, distance from posterior nasal spine to tip of the soft palate, 36.01 ; MP-H, distance from hyoid to mandibular plane, 20.75; $\mathrm{N}$-ANS, vertical measurement from nasion to anterior nasal spine, 50.02; ANS-Gn, vertical measurement from anterior nasal spine to gnathion, 72.50; GoGn$\mathrm{SN}$, measurement from gonion to gnathion to sella 54.96.

The patient underwent three all-night polysomnographic recordings ${ }^{16}$, on consecutive nights, in which electroencephalogram (C3/A2, C4/A1), electrooculogram, submentalis electromyogram, 
Table 1. Polysomnographic data of a patient (Case A) with Pierre Robin sequence and obstructive sleep apnea.

\begin{tabular}{|c|c|c|c|c|c|}
\hline & & night 1 & night 2 & night 3 & mean \\
\hline Total time in bed & $\min$ & 461 & 539 & 493 & 497.6 \\
\hline \multirow[t]{2}{*}{ Total sleep time } & $\min$ & 453 & 529 & 481 & 487.6 \\
\hline & $\% *$ & 98.2 & 98.1 & 97.5 & 97.9 \\
\hline \multirow[t]{2}{*}{ Total time awake } & $\min$ & 8 & 10 & 12 & 10.0 \\
\hline & $\% *$ & 1.7 & 1.8 & 2.4 & 1.9 \\
\hline Sleep latency & $\min$ & 3 & 5 & 2 & 3.3 \\
\hline REM latency (St l) & $\min$ & 42 & 59 & 38 & 46.3 \\
\hline REM latency (St 2) & $\min$ & 40 & 56 & 36 & 44.0 \\
\hline \multirow[t]{2}{*}{ Stage REM } & $\min$ & 57 & 41 & 48 & 48.6 \\
\hline & $\% * * *$ & 12.5 & 7.7 & 9.9 & 10.0 \\
\hline \multirow[t]{2}{*}{ REM density } & $\min$ & 3.2 & 3.9 & 3.1 & 3.4 \\
\hline & $\% * * *$ & 5.6 & 9.0 & 6.4 & 7.0 \\
\hline \multirow[t]{2}{*}{ NREM stages } & $\min$ & 396 & 488 & 433 & 439 \\
\hline & $\% * * *$ & 87.4 & 92.2 & 90.0 & 89.8 \\
\hline \multirow[t]{2}{*}{ Stage 1} & $\min$ & 4 & 3 & 6 & 4.3 \\
\hline & $\% * * *$ & 0.8 & 0.5 & 1.2 & 0.8 \\
\hline \multirow[t]{2}{*}{ Stage 2} & $\min$ & 289 & 348 & 270 & 302.3 \\
\hline & $\% * * *$ & 63.7 & 65.7 & 56.1 & 61.8 \\
\hline \multirow[t]{2}{*}{ Stage 3} & $\min$ & 7 & 11 & 17 & 11.6 \\
\hline & $\% * * *$ & 1.5 & 2.0 & 3.5 & 2.3 \\
\hline \multirow[t]{2}{*}{ Stage 4} & $\min$ & 96 & 126 & 140 & 120.6 \\
\hline & $\% * * *$ & 21.1 & 23.8 & 29.1 & 24.6 \\
\hline Arousals & $\mathbf{N}$ & 119 & 130 & 106 & 118.3 \\
\hline Awakenings & $\mathbf{N}$ & 6 & 9 & 5 & 6.6 \\
\hline Apnea index & & 23.6 & 30.0 & 28.7 & 27.4 \\
\hline$A+H$ index & & 37.4 & 45.1 & 51.1 & 44.5 \\
\hline Baseline Sat02 & $\%$ & 98 & 98 & 99 & 98.3 \\
\hline Lowest Sat02 & $\%$ & 83 & 81 & 84 & 82.6 \\
\hline $\mathrm{SaO} 2<90 \%$ & $\min$ & 6.9 & 5.7 & 7.2 & 6.6 \\
\hline Longest apnea & $\mathbf{s}$ & 57 & 64 & 59 & 60.0 \\
\hline
\end{tabular}

$\% *$, percentagem in relation to total time in bed; \%**, percentagem in relation to total REM sleep time; $\% * * *$, percentagem in relation to total sleep time; Sat02, oxygen saturation; Sat02 < $90 \%$, sleep time with Sat $02<90 \%$; apnea index, number of obstructive per hour; $\mathrm{A}+\mathrm{H}$ index, number of obstructive apneas + hypopneas per hour.

electrocardiogram (modified V2 lead), and anterior tibialis electromyogram were recorded. Respiration was monitored by abdominal and thoracic strain gauges, nasal and oral airflow was monitored by thermistors. Transcutaneous oxygen saturation (02Sat) was monitored by finger oxymetric method. Snoring sounds were recorded and video recordings were taped. The study was performed in a pleasant room of the Sleep Disorders Center, which is light-proofed, sound-attenuated, controled at a constant temperature $\left(21^{\circ} \mathrm{C}\right)$ and furnished with a comfortable bed. The results in the three nigths (Table 1) were homogeneous, showing total time in bed and total sleep time adequate for the age. Sleep latency and REM latency were short. Time spent in each stage showed a moderate reduction of stages 3 and 4 marked reduction of stage REM. There were numerous arousals associated with apneas and hypopneas. The apneas and hypopneas were predominantly obstructive, with a mean apnea index of $27.4 / \mathrm{h}$; the mean respiratory disturbance index (apnea + hypopnea index) was $44.5 / \mathrm{h}$. The longest apnea was $64 \mathrm{~s}$ duration, accompained by bradycardia and followed by tachicardia. The lowest heart rate 
was $49 /$ min. The mean basal Sa02 was $98 \%$; the mean minimum was $82 \%$. During sleep, she frequently coughed and moaned; snored loudly with pauses related to the apneas; presented cyanosis of the extremities; had intense chocking movements associated with the obstructive episodes. While asleep, she often changed body position, at times sitting on the edge of the bed with head tilted forward, and at times kneeling on the bed with thorax touching the thigs and head forward with fronthead laying on the bed.

In order to evaluate daytime sleepiness, the Multiple Sleep Latency Test (MSLT) was conducted on two noncosecutive days using standardized technique ${ }^{4,18}$ allowing the subject to sleep, at $2 \mathrm{~h}$ intervals, starting at $0900 \mathrm{~h}$, for a total of 5 consecutive sleep options. The test was performed in the same room as for all-night polysomnography. Any external factor that could prevent sleep start was avoided. The patient wore confortable everyday clothes during the test. In the intervals between sleep the patient stayed out of the bedroom and did not nap. The records were analised regarding: $a$. Sleep latency (the time from ligths off to the onset of sleep); and $b$. REM latency (the time from sleep onset to beginning of stage REM). The MSLT showed, on the first day the following latencies: $3 \mathrm{~min}, 6 \mathrm{~min}, 1 \mathrm{~min}, 2 \mathrm{~min}, 7 \mathrm{~min}$, with a mean latency of $3.8 \mathrm{~min}$. On the second day, the latencies were $4 \mathrm{~min}, 4 \mathrm{~min}, 2 \mathrm{~min}, 7 \mathrm{~min}, 5 \mathrm{~min}$, with a mean latency of $4.4 \mathrm{~min}$. Stage REM sleep was not detected in either of the tests, on both days.

\section{COMMENTS}

The Pierre Robin sequence, also called Robin anomalad, is characterized by several degrees of micrognathia severity, glossoptosis and palatal malformation. In our case, marked micrognathia is associated with reduction of the buccal space and glossoptosis. As usual in this malformation, the tongue size is normal but bucolingual disproportion is due to micrognathia, increasing the glossoptosis. High thin palate was evidenced by nuclear magnetic resonance. The sequence may be accompanied by other congenital anomalies. In this case report bilateral temporomandibular ankylosis was present but, as usual in Pierre Robin sequence, the neurodevelopmental outcome was normal ${ }^{5}$.

In several cases in which mandibular hypoplasia is prominent, the tongue tends to encroach on the airway leading to breathing and feeding difficulties, bouts of cyanosis, and chocking spells, as mentioned by Robin ${ }^{21}$ to whom the first use of the term "glossoptosis" is attributed. Airway obstruction, and related hypoxia, carries a high mortality risk in Pierre Robin sequence. Children with craniofacial anomalies may present OSAS even in the first weeks of life $e^{12,14,17,19,23}$. In the case here described, micrognathia was noticed at birth, soon followed by chocking and feeding difficulties. A history of repetitive broncopneumonia in the first months of life suggests it is related to swallowing impairment.

Temporomandibular condyle ankylosis was demonstrated in the articular roentgenogram, computerized tomography, and nuclear magnetic resonance. The level of obstruction in the pharynx, appeared as the narrowing of the PAS and evidenced in the cephalometrics. This technidque provides useful information on bony and soft tissue abnormalities of the upper airways in OSAS patients ${ }^{1,11,13,20,22}$. Such thorough radiologic evaluation gives relevant information for future therapeutic planning of complex mandibular malformations.

Polyssomnography determined the obstructive nature of the apneas, quantified its severity and the secondary systemic impairment. This information is fundamental in the evaluation of the Pierre Robin sequence apneas ${ }^{3.7}$. Our data agreed with others that apneas in these patients are predominantly obstructive $\mathbf{3}^{3,7,8,14,15}$.

The MSLT documented objectively the intense daytime sleepiness but without stage REM sleep as is usually the pattern in patients with the excessive daytime sleepiness caused by OSAS. We suppose that the patient's life long history of alertness impairment is in fact related to the OSAS secondary to mandibular malformation since airway obstruction was present since birth. Contrary to the frequent presence of restlessness and irritability during the day that are manifestations of OSAS in children our patient showed sleepiness as the main daytime feature throughout her life. 
Patients with Pierre Robin sequence and related craniofacial anomalies who present respiratory sleep symptoms and daytime sleepiness should be completely worked out including: radiologic, polysomnographic and MSLT evaluation in order to determine the sites and severity of obstruction, as well as systemic impairment ${ }^{2,3,8,9}$. Such evaluation should guide treatment planning.

Acknowledgments: We are indebt to Beatriz Lefevre for psychological evaluation and support.

\section{REFERENCES}

1. Adair NE, Mathews BL, Haponik EF. Techniques to assist selection of appropriate therapy for patients with obstructive sleep apnea. Head Neck Surg 1991, 2: 81-86.

2. Augarten A, Sagy M, Yahav J, Barzylay Z. Management of upper airway obtruction in the Pierre Robin syndrome. Br J Oral Manxillofac Surg 1990, 28: 105-109.

3. Bull MJ, Givan DC, Sandove AH, Bixler D, Hearn D. Improved outcome in Pierre Robin sequence: effect of multidisciplinary evaluation and management. Pediatrics 1990, 86: 294-301.

4. Carskadon MA, Dement WC, Mitler MM, Roth T, Westbrook PR, Keenan S. Guidelines for the Multiple Sleep Latency Test (MSLT): a standard measure of sleepiness. Sleep 1986, 9: 519-524.

5. Cozzi F, Pierro A. Glossoptosis-apnea syndrome in infancy. Pediatrics 1985, 75: 836-843.

6. Debery-Borowicki B, Kukwa A, Banks R. Cephalometric analysis for diagnosis and treatment of obstructive sleep apnea. Laryngoscope 1988, 98: 226-234.

7. Freed G, Pearman MA, Brown AS, Barot LR. Polysomnographic indications for surgical intervention in the Pierre Robin sequence: acute airway managment and follow-up studies after repair and take-down of tongue-lip adhesion. Cleft Palate J 1988, 25: 151-155.

8. Gilhooly JT, Smith JD, Howell LL, Deschaine BL, Richey SL. Bedside polysomnography as an adjunct in the management of infants with Robin sequence. Plast Reconstr Surg 1993, 92: 23-27.

9. Guilleminault C, Mondini S. Need for multi-diagnostic approaches before considering treatment in obstructive sleep apnea. Laryngsocope 1988, 98: 226-234.

10. Guilleminault C, Riley R, Powel N. Sleep apnea and cephalometric measurements. Chest 1984, 86: 793-794.

11. Guilleminault C, Partinen M, Praud JP, Quera-Salva MA, Powel N, Riley R. Morphometric facial changes and obstructive sleep apnea in adolescents. J Pediatr 1989, 114: 997-999.

12. Heaf DP, Helms PJ, Dinwiddie R, Matthew DJ. Nasopharyngeal airways in Pierre Robin sequence: effect of multidisciplinary evaluation and management. Pediatrics 1990, 86: 294-301.

13. Jamieson A, Guilleminault C, Partinen M, Quera-Salva MA. Obstructive sleep apneic patients have craniomandibular abnormalities, Sleep 1986, 9: 469-477.

14. Letica M, Adrich MS. Obstructive sleep apnea in Pierre Robin and related craniofacial syndromes. In: Association of Professional Sleep Societies Annual Meeting Abstracts. Phoenix, U.S.A.: Association of Professional Sleep Societies, 1992, p 171.(abstr).

15. Ogborn MR, Pemberton PJ. Late development of airway obstruction in the Robin anomalad (Pierre Robin sequence) in the newborn. Aust Pediatr J 1985, 21: 199-200.

16. Rechtschaffen A, Kales A. A Manual of standardized terminology, technique and scoring systems for sleep stages of human subjects. Los Angeles: Brain Information Service, University of Carlifornia, 1986.

17. Reimão R. Contribuição ao estudo dos distúrbios do sono na infância. Tese. Faculdade de Medicina, Universidade de São Paulo, São Paulo, 1983.

18. Reimão R. Teste das Latências Múltiplas do Sono: técnica, indicação e interpretação. Reun Neurofisiol Clin 1990, 5: 45-46.

19. Reimão R, Diament A. Sono na infância. São Paulo: Sarvier, 1985.

20. Riley RW, Guilleminault C, Herran J. Cephalometric analysis and flow volume loops in obstructive sleep apnea patients. Sleep 1983, 6: 304-317.

21. Robin P. Glossoptosis due to atresia and hypotrophy of the mandibule. Am J Dis Child 1934, 48: 541-547. 22. Series F, Pierre SS, Carrier G. Surgical correction of nasal obstruction in the treatment of mild sleep apnoea: importance of cephalometric in predicting outcome. Thorax 1993, 48: 360-363.

23. Williams AJ, Williams MA. Walker CA, Bush PG. The Robin anomalad (Pierre Robin sequence): a followup study. Arch Dis Child 1981, 56: 663-668. 